\title{
The Learning Strategy of The Flipped Classroom With Gamification As An Alternative Learning Solution During The Covid-19 Pandemic
}

\author{
Bella Dwi Lestari ${ }^{1}$, Sri Hastuti Noer ${ }^{2}$ \\ \{b.dwilestari@yahoo.com ${ }^{1}$, hastuti_noer@yahoo.com ${ }^{2}$ \} \\ Mathematics Education, Lampung University, Lampung, Indonesia ${ }^{1,2}$
}

\begin{abstract}
The purpose of this research is to analyze the Flipped classroom learning strategy when combined with gamification as a learning solution during the COVID-19 pandemic and to provide recommendations for teachers, learning designers, and practitioners regarding the implementation of the two learning strategies. This study uses a qualitative content analysis method. Based on the results of the analysis, giving gamification elements into learning has the potential to increase the quality of mathematics learning. Several research results state that the use of the Flipped classroom strategy and the use of gamification have a positive impact on learning so that it can be a suggestion for learning during the COVID 19 pandemic, especially in mathematics learning.
\end{abstract}

Keywords: Flipped Classroom, Gamification, Mathematics Learning

\section{Introduction}

Distance learning is an alternative learning option during the Covid-19 Pandemic, physical contact or face-to-face contact between humans must be minimized from daily life and transformed into a new tradition called "New Normal" [1]-[4]. Technology is needed to support the distance learning process [5]-[7]. The rapid development of information technology can't be avoided its effect on education [8], [9]. With rapid technological advances, the use of technology in learning mathematics is very well used because it produces positive results in learning and understanding concepts [10], [11]. A teacher must improve the learning strategy and strive for innovation in the process of learning mathematics [12]-[14]. At present, many innovations in mathematics learning can be used to maximize the learning process.

Researchers and practitioners have investigated effective methodologies and instructing techniques to include and spur understudies in the learning process, some of them are Flipped classroom [11], [15], [16] and gamification [17] The Flipped classroom is an innovation that helped to learn a system that states critical thinking and learning with partners in the classroom [18], [19]. In a Flipped classroom, learning activities that are usually carried out in class are carried out outside the classroom. Thus, activities in the classroom can be focused on exercises that can animate understudies to think at a more significant level [11], [18], [20]-[24]. Flipped classrooms need to be designed so that they have more value in terms of learning design. Giving design elements of gamification into learning will potentially increase the quality of mathematics learning. 
Gamification is the concept of applying the principles and mechanisms of play in non-game activities, especially in education. This learning utilizes components in games or computer games that plan to persuade understudies, as ideas that utilization game-based mechanics, style, and thinking games to connect with understudies, rouse activities, advance learning and solve problems. Based on previous research, the use of learning Flipped classroom and gamification has been widely used in various studies [17], [18], [21], [25]-[33]. However, there have been no previous studies that analyzed the Flipped classroom learning strategy combined with gamification as a learning solution during the COVID-19 pandemic. Therefore, this article will discuss how the Flipped classroom learning strategy combined with gamification as a learning solution in the COVID-19 pandemic and as input for future education. Therefore, the novelty in this article is to discuss the Flipped Classroom learning strategy when combined with gamification and the implementation of these two strategies in learning during the COVID-19 pandemic.

\section{Method}

\subsection{Research Design}

The qualitative analysis method is the research design used in this study. A topical investigation that focusing on the connection between substance and setting which comprises of ordering, putting together, contrasting, and separating hypothetical ends from different articles or exploration [1].

\subsection{Participant}

Participants in this study consisted of 20 literature that discusses Flipped classroom learning strategies and gamification, the literature used is an article sourced from various databases such as Scopus, Springer, IEEE explore, and ScienceDirect. The author analyzes abstracts and related contexts to generate some ideas or find relationships in finding learning strategies for Flipped classroom and gamification. This study uses several criteria, the sample criteria include inclusion criteria that determine whether or not the sample can be used. The inclusion criteria in this study were a literature that was selected to be a participant published between 2014-2020, related to flipped classrooms and gamification aimed at describing flipped classrooms and gamification.

\section{Result and Discussion}

\subsection{The Flipped Classroom}

In the 21st century, one of the learning strategies is a flipped classroom. In learning with the flipped classroom, to maximize time in the classroom, students are given a video, which is an instructional video created by the teacher. The video is given to students before learning begins. [18], [34]. When in class, the teacher helps students who have difficulties and provides 
problems or activities that are more challenging for students who have understood the concept of the lesson [24]. There are four pedagogical dimensions to explain why the flipped classroom supports student-centered learning theory, namely personalization, higher-order thinking, selfdirection, and collaboration [20]. In Bloom's Taxonomy, cognitive levels such as remembering and understanding can be done with the help of instructional video instructional in Flipped classroom learning, meanwhile, learning in the classroom is focused on the cognitive level of application, analysis, evaluation and creating [21], [31]. The basic principle of this flipped learning is that time outside the classroom is very structured, preparation for assessment can be done before learning in class by the teacher, time in class must involve the process of problemsolving and cooperative discussion, and teacher feedback is done in the classroom. Some things that must be considered in this learning are the importance for teachers to compile instructional videos, students know the material through videos that are done before learning in the classroom, students are given a stimulus to make preparations, students' knowledge is assessed before class starts and classroom learning involves higher-order thinking processes [21]. Examples of instructional videos made by teachers in Flipped classroom learning can be seen in Figure 1

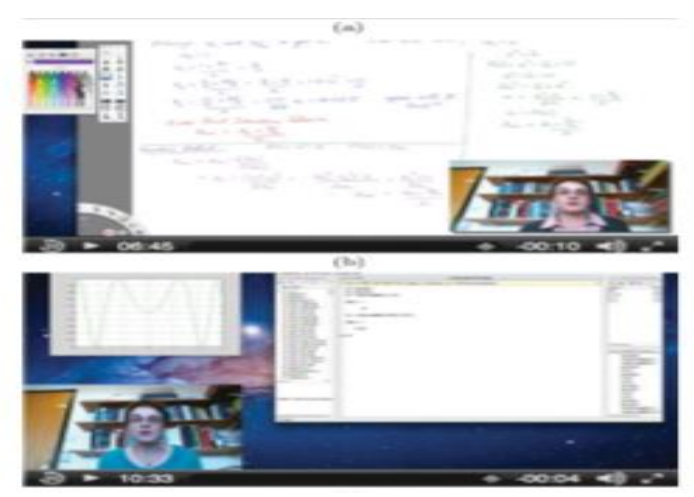

Fig 1. Examples of instructional videos used in learning Flipped classroom

\subsection{Gamification}

Gamification is the concept of applying the principles and mechanisms of the game in non-game activities into learning [32], [33]. Nick Pelling was the first person to use the term gamification in 2002. Gamification is a learning approach using elements in games or video games to motivate students in the learning process, gamification can maximize the enjoyment and engagement of the learning process, besides this media can be used to capture things that interest students and inspire them to continue to learn. [35] Gamification building engagement with certain groups. The steps of applying gamification in learning recognize the learning objectives, determine the big idea, create a game scenario, create a design of learning activities, build groups, and apply game dynamics. Many gamification services can be used in learning, 
Juan José Bullón et all uses two well-known gamification services namely Socrative and Kahoot. [29]. Socrative is a student response system that allows teachers to create quizzes or interactive games that involve students directly or in real-time, while Kahoot is a multiple choice quiz game or discussion and survey that can be used by anyone and is not limited to the level of age and subject matter. In Barbara's research, examples of Kahoot and Socrative application forms can be seen in Figure 2 [21]

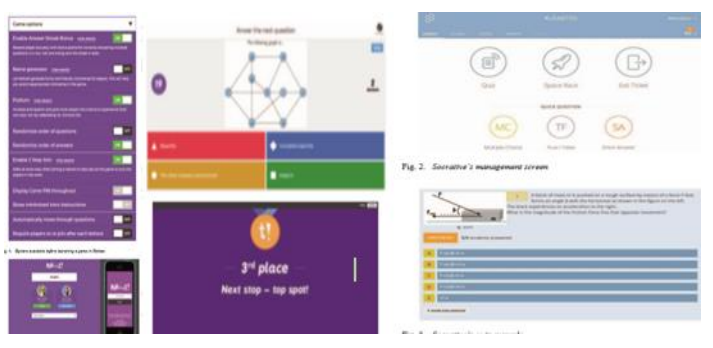

Fig 2. Kahoot and Socrative application

\subsection{Relevant research on using flipped classroom and gamification}

Based on some previous research that has been done, research related to the application of Flipped classroom learning has been carried out, research by Chung Kwan Lo \& Khe Foon Hew states that students in Flipped classroom classes significantly outperform students in traditional classes and independent studies online. Also, Flipped classroom learning encourages students' cognitive involvement for the better. The students 'interview findings show that peer interaction in learning Flipped classroom is very important to encourage students' mathematical achievement and cognitive involvement [18]. Kaushal et al Chang state that there are significant differences between the implementation of the flipped classroom and conventional learning, a significant difference is seen in student achievement and motivation, ie students with flipped classroom learning are better than students in conventional classes. In the flipped classroom, students with low achievement get more attention from the teachers and discuss problems to understand the concept. Therefore, learning like this can help those who have low achievement to improve their performance in learning [11]. Betty Love, Angie Hodge, Neal Grandgenett \& Andrew W. Swift in their research they found that students in flipped classrooms continued to perform better than students in traditional classes on the final exam, which represented conceptual understanding. This result is important because students in flipped classrooms not only learn the mathematical skills required in linear algebra but also students are more interested in enjoying the class because it triggers and maintains students' interest in mathematics is very important[36]. Barbara M. Johnston explained that most students liked the learning videos made by the teacher. The flipped classroom is still recommended to be applied in learning because it suits different student learning styles, and time in class can be used more productive [21]. Caleb Adams \& Anthony Dovein their study stated that participation in Flipped classroom learning substantially increased achievement. However, there was no difference between students' 
beliefs about learning mathematics between the two groups. To understand the success of Flipped classroom learning students must focus on instructional videos and a consistent presence is needed in practicing the techniques shown in lecture videos and class learning. [24]

Research on gamification has also been widely applied in several previous studies, Yogi Udjaja, Vincent Sadino Guizot dan Natalia Chandra in their research developing gamificationbased interactive learning games to support students understanding mathematical material, the purpose of this application is to help students to learn mathematics interactively and attractively and be used to convey mathematical material easily[28]. Andrey V. Kirillova in his research mentioned that gamification can help create a beneficial learning environment, ensure high involvement of all participants in the education process, significantly reduce the impact of adverse factors in learning. Gamification can increase student motivation for a long time, turning student training into educational and interesting games. Games can generate interest in students, create a pleasant learning environment, and continue to motivate to move to the next level, get awards, and complete assignments. Gamification, changing student behavior to contribute to the formation of new habits. This can be in the form of modernization of educational space aimed at improving students' attitudes towards learning, planting healthy lifestyles, skill-building, and others. New habits students have the desired effect of creating a more effective education system. Juan José Bullón revealed that, Subsequent to dissecting the criticism given by understudies through polls, it appears to be that the utilization of gamification devices, for example, Socrative and Kahoot is invited. The best approach to improve understudies' discernments in this field is to give more opportunity to address questions or make tests, every understudy can follow their means. In any case, it very well may be said that utilizing this plan in all tests will decrease parts of amusement and appeal. The advantage for the instructor is that they can actuate understudy support. By utilizing Socrative or Kahoot, understudies are compelled to react, which causes them to build up their aptitudes and abilities. Additionally, utilizing this gamification can permit space for understudies to think. However, not exclusively in the discussion advanced along these lines, yet cooperation is additionally encouraged[29]

\subsection{Strategy Flipped Classroom is combined with gamification in mathematics learning}

Learning strategies make the learning process more active, learning strategies depend on the teaching methods used by the teacher. [37]. During the COVID-19 pandemic, face-to-face learning must be reduced to minimize the spread of the coronavirus, especially in the learning process at school. One learning method that can be applied is the flipped classroom, which provides student-centered learning facilitation through online learning. In this Flipped classroom, students are required to be responsible for their learning outside the classroom. This is realized by learning through learning videos provided by the teacher. In this way, students will be ready to do learning in class, time in class can be optimized by active and innovative learning, such as discussion, problem-solving, presentations, or project-based learning. The concept of student-centered learning offered by flipped classroom must indeed 
be supported by students' willingness to learn. In other words, students must have high motivation to follow the entire stages of the flipped classroom, starting from watching video learning outside the classroom, discussing solving problems in the classroom, and working on assignments or projects given by the teacher. Therefore, teachers and learning designers need to provide mechanisms that can ensure the high motivation of student learning to remain. To do this, gamification can be applied in learning Flipped classroom. The use of game design elements in gamification will help meet students' needs for competence, autonomy, and relationships.

To see an illustration of the use of gamification in the flipped classroom, the next will be discussed mathematical learning design that has been implemented by Lo \& Hew, which has combined Flipped classroom and gamification into mathematics enrichment classes. When outside the classroom, students are asked to watch learning videos to recall the material they have previously learned and study the basic material. After that, students work on online follow-up exercises. The execution of this exercise is aimed at making students able to apply their knowledge and understanding after they watch the video. Class activities begin with quizzes and review pre-learning materials. After that, students listened to the teacher's brief presentation and continued with individual exercises and problem-solving in groups. In this learning system, game design elements are used in the learning management system. These elements are points, badges, progress charts, and leaderboards. Points are awarded to students if they watch videos, complete online follow-up exercises, and additional assignments. Badges are given when students have completed all pre-learning activities before class. A different badge is also given if students complete all pre-learning activities each week. The progress graph is used to show the progress of the student learning process every time. Finally, leaderboards are used to show student rankings based on points that have been obtained.[18] Hung et al in his research applying Flipped classroom to game-based learning. Students are given directions to watch learning videos and do practice questions before entering class. When watching a video, students can see their level of participation and ability through the points shown. The execution of the exercises is aimed at making students aware of their ability to develop the material they are learning. When in class, students are conditioned to do gamebased learning. In this study, all students are divided into heterogeneous groups consisting of 3 to 4 students. Each student in the group is given the role of general, tactician, and soldier. The assignment of this role is based on students' mathematical abilities, generals for highability students, tacticians for medium-ability students, and soldiers for low-ability students. The task of each group is to discuss and solve mathematical problems obtained from textbooks or learning videos that they have watched. The solution to this problem is used to conquer the area of the map provided by the teacher (this is an element of the story in the game). After the group finished solving the problem, they were asked to appoint one of the group members to present their results. If a general presents it, then the group's value is 1 point, if a tactician scores 2 points, and if a soldier scores 3 points. [30] Two previous studies in mathematics learning have illustrated how a flipped classroom is combined with gamification. Both of these can be used to seek active and enjoyable mathematics learning so that it has a positive 
impact on student learning outcomes and motivation. Using the game method effectively expected against student motivation.[38]

\subsection{How to apply a flipped classroom and gamification in online learning?}

Social change that suddenly occurs due to the spread of Covid-19 had caused stutter in a teaching-learning activity. The entire stage of education should be able to take transformation to drastically adapt to learning from home through online activity, the solution is educators are required to design learning by utilizing online media. The learning system is implemented through computer equipment that connects to internet network connection or in other words online learning. In various countries, several cities fall into the red zone category. In the red zone lockdown policy begins prevailing to avoid increasing cases and the victims due to infectious disease, therefore online learning be an alternative that can be used.

The syntax of the flipped classroom model combined with gamification in online learning consist of (1) students learning to make questions by themselves. Students watch the learning video by themselves at home and take notes or questions that they are not yet understood. Learning that is usually done in the classroom is transferred to the virtual classroom such as the use of "Google classroom" while the coordination through WhatsApp application. Google Classroom is a free online platform, while the teacher can create virtual classes and invite or add the students into the group. This can help the teacher to arrange the lesson material. In google classroom, the teacher has coordinated the learning material, namely the learning videos made by the teacher as well as the learning videos from Youtube various other sources of teaching materials. (2) The students enter the class via the web and discuss it. Learning via web begins with students filling out the attendance list first trough "google classroom" then the students with the help of the teacher discussing on the web. The use of zoom applications and other similar applications can help the students in discussing with the teacher without doing process directly learning. (3) Apply students' abilities in video projects. Students are asked to make a learning video by their version, videos are made with the aim so that students are more creative in the use of technology and help them to remember the material. (4) Measuring the ability of students with design gamification, measuring students understanding done online can be done by utilizing a gamification based application Including being able to use the Quizz application, Kahoot, and other applications. The use of gamification keeps students motivated to follow the learning consistently.

Learning using flipped classroom strategy combined by gamification can give many advantages in the process learning at during COVID 19 pandemic, however behind there are many advantages of implementing this strategy, there may be a challenge in it is implementation, the challenge that may be faced is students are not ready or not familiar with the flipped classroom learning process so that the students not interested in learning like this. Unprepared pre-learning assignment, inability to ask in learning activities outside the classroom Inability to understand video content, increasing learning load, inability to access prepared learning material may be very challenging. Therefore in implementing this strategy, every component of resulting learning must be considered. Firstly, learning video needs to be 
well designed so that it optimal in facilitating students learning. The teacher needs to observe student's characteristics in their class to make a video that is aimed for students itself and sure it can be combined with element gamification. Secondly, it is necessary to practice exercise that aims to provide opportunities for students to apply their knowledge, with the exercise also can be known which students have conducted pre leaning activities. Third, the use of social media such as WhatsApp and others needs to be utilized to minimize meetings between students and teachers. Fourth, the activity of reviewing material that has been learned by students during independent learning outside the classroom needs to be done at the beginning of learning activities in the classroom. This is intended so that teachers can provide feedback to students regarding learning. Also, by doing this activity the teacher can see the misconceptions experienced by students and immediately correct them. Fifth, the problemsolving process is more emphasized during the learning process. Sixth, the teacher needs to provide continuous, timely feedback to students about developing their learning. This will provide insight to students about the distance between the reality of their learning abilities and the objectives to achieve.

\section{Conclusion}

The conclusions that can be obtained based on the discussion in this article are the elements of game design in gamification can be used in learning to complement the flipped classroom approach so that students have the motivation to learn to participate fully in learning and can be used as learning strategies during the COVID-19 pandemic. Thus, students will get optimal results from what is student-centered learning can offer, namely personalization, high-level thinking, self-direction, and collaboration. With designs being considered from a variety of theoretical perspectives, the combination of flipped classroom and gamification has the potential to develop students' abilities and skills. Furthermore, the combination can increase the intensity of students to interact with technology. Thus, this kind of learning strategy will provide space for students to improve their technological literacy.

\section{Acknowledgments.}

Primarily, i would thank God for being able to complete this article with success, and to thank my lecture and advisors: Dr. Sri Hastuti Noer, M.Pd whose valuable guidance has been the ones that has been the ones that helped me complete this articel

\section{References}

[1] Siripongdee K, Pimdee P, Tuntiwongwanich S. A Blended Learning Model with IoT-based technology: Effectively used when the COVID-19 Pandemic? J Educ Gift Young Sci. 2020;8(2):905-17.

[2] Mulenga EM, Marban JM. Prospective Teacher's Online Learning Mathematics Activities in The Age of COVID-19 : A Cluster Analysis Approach. Eurasia J Math Sci Technol Educ. 2020;16(9):19.

[3] Shahzad A, Hassan R, Abdullah NI, Hussain A, Fareed M. COVID-19 Impact On E-Commerce Usage: An Empirical Evidence From Malaysian Healthcare Industry. Humanit Soc Sci Rev. 
2020;8(3):599-609.

[4] Stukalo N, Simakhova A. COVID-19 Impact on Ukrainian Higher Education. Univers J Educ Res. 2020;8(8):3673-8.

[5] Ahmad S, Zulfikar T, Hardiana F. The Use Of Social Media WhatsApp Among English Education Students For Solving Thesis Writing Problems. Humanit Soc Sci Rev. 2020;8(3):447-55.

[6] Masrizal, Fata IA, Erdiana N. Investigating In-Service Teachers' Perceptions On Online And Autonomous Learning. Humanit Soc Sci Rev. 2020;8(3):456-65.

[7] Wibawa B, Paidi. The Development Of Blended Learning Based On Handphone For Computer System Subject On XI Grade Of SMKN 1 Bengkulu City. Humanit Soc Sci Rev. 2019;7(3):497502.

[8] Van VH. Identify Methods Of Teaching And Learning To Create Interest, Self-Study, And Creativity Of Students. Humanit Soc Sci Rev. 2020;8(3):646-56.

[9] Mohamad M, Ghazali N, Hashim H. Secondary School Students' Perception on the Use of Google+ towards Improving ESL Writing Skills. Int J Emerg Technol Learn. 2018;13(9):224-38.

[10] Lazakidou G, Retalis S. Using computer supported collaborative learning strategies for helping students acquire selfregulated problem-solving skills in mathematics. Comput Educ. 2010;54(1):313.

[11] Bhagat KK, Chang C-N, Chang C-Y. The Impact of the Flipped Classroom on Mathematics Concept Learning in High School. Educ Technol Soc. 2016;19(3):124-32.

[12] Ayu I, Astuti K, Marhaeni AAIN. Pengaruh Pendekatan Matematika Realistik terhadap Prestasi Belajar Matematika ditinjau dari Kemampuan Numerik. E-Journal Progr Pascasarj Univ Pendidik Ganesha Jur Pendidik Dasar. 2013;3(3):2.

[13] Utami SD, Asnawati R, Coesamin M. Efektivitas Penerapan Problem Based Learning Ditinjau dari Kemampuan Representasi Matematis. 2016;2(3):56-63.

[14] Supriadi N, Syazali M, Lestari BD, Dewi ES, Utami LF, Afriansyah L, et al. The Utilization of Project Based Learning and Guided Discovery Learning: Effective Methods to Improve Students' Mathematics Ability. Al-Ta'lim J. 2018;25(3):262-71.

[15] Chen Y, Wang Y, Kinshuk, Chen NS. Is FLIP enough? or should we use the FLIPPED model instead? Comput Educ. 2014;7(9):16-27.

[16] Fautch JM. The Flipped classroom for teaching organic chemistry in small classes: Is it effective? Chem Educ Res Pract. 2015;16(1):179-86.

[17] Rincon-Flores EG, Gallardo K, Fuente JM de la. Strengthening an Educational Innovation Strategy: Processes to Improve Gamification in Calculus Course through Performance Assessment and Metaevaluation. Int Electron J Math Educ. 2018;13(1):1-11.

[18] Lo CK, Hew KF. A comparison of flipped learning with gamification, traditional learning, and online independent study: the effects on students' mathematics achievement and cognitive engagement. Interact Learn Environ. 2018;26(8):1-18.

[19] Abeysekera L, Dawson P. Motivation and cognitive load in the flipped classroom: Definition, rationale and a call for research. High Educ Res Dev. 2015;34(1):1-14.

[20] Koh JHL. Four pedagogical dimensions for understanding flipped classroom practices in higher education: A systematic review. Educ Sci Theory Pract. 2019;19(4):14-33.

[21] Barbara M. Johnston. Implementing a flipped classroom approach in a university numerical methods mathematics course. Int J Math Educ Sci Technol. 2016;48(4):485-98.

[22] Ramadhani R, Umam R, Abdurrahman A, Syazali M. The Effect Of Flipped-Problem Based Learning Model Integrated With LMS-Google Classroom For Senior High School Students. J Educ Gift Young Sci. 2019;7(2):137-58.

[23] Tugun V. Impacts and Opinions on the Technology Self-Sufficiency of the Students who are Coding Education in the Flipped Classroom Adapted to the ARCS Motivation Model. TEM J. 2018;7(2):366-71.

[24] Adams C, Dove A. Calculus Students Flipped Out: The Impact of Flipped Learning on Calculus Students' Achievement and Perceptions of Learning. PRIMUS Probl Resour Issues Math Undergrad Stud. 2017;28(6):1-29.

[25] Sitorus MB. Studi Literatur mengenai Gamifikasi untuk Menarik dan Memotivasi: Penggunaan 
Gamifikasi saat ini dan Kedepan. 2016. (Studi Literatur - Tugas Seminar 1 Pascasarjana Teknik Elektro).

[26] Prambayun A, Farozi M. Pola Perancangan Gamifikasi untuk Membangun Engagement Peserta didik Dalam Belajar. In: Seminar Nasional Teknologi Informasi dan Multimedia. 2015. p. 7-21.

[27] Yusuf H. Pengembangan Gamifikasi dalam Proses Pembelajaran. J TICOM. 2016;5(1):2-3.

[28] Udjaja Y, Guizot VS, Chandra N. Gamification For Elementary Mathematics Learning In Indonesia. IJECE Int J Electr Comput Eng. 2018;8(5):375-83.

[29] Bullón JJ, Encinas AH, Sengül S. Analysis of student feedback when using gamification tools in Math subjects. IEEE Glob Eng Educ Conf. 2018;4(18):1818-23.

[30] Hung CY, Sun JCY, Liu JY. Effects of flipped classrooms integrated with MOOCs and game-based learning on the learning motivation and outcomes of students from different backgrounds. Interact Learn Environ. 2019;27(8):1028-46.

[31] N S. Flipping an introductory programming course-Yes you can! JComputSciColl. 2013;28(6):186-188

[32] Arif FKM, Zubir NZ, Mohamad M, Yunus MM. Benefits and Challanges of Using Game-Based Formative Assessment Among Undergraduate Students. Humanit Soc Sci Rev. 2019;7(4):203-13.

[33] Zakaria Z, Rosli DB. Adaption Of The Gamification Hexad Player Types And Cognitive Awerness In An Engineering Student. Humanit Soc Sci Rev. 2019;7(5):626-38.

[34] Zou D. Gamified Flipped EFL Classroom for primary education : student and teacher perceptions. J Comput Educ. 2020;7:213-28.

[35] Inchamnan W. Gamification Design Process For The Aging Society In Thailand. Humanit Soc Sci Rev. 2019;7(1):47-54

[36] Love B, Hodge A, Grandgenett N, Swift AW. Student learning and perceptions in a flipped linear algebra course. Int J Math Educ Sci Technol. 2018;43(3):317-24.

[37] Elsamanoudy GEA, Abdelaziz NS. Teaching strategies for gifted students in interior design program. J Educ Gift Young Sci. 2020;8(2):819-28.

[38] Pratiwi, Istiyowati LS. Simulation and Games Based Learning Model for Learning Math in Higher Education. Univers J Educ Res. 2020;8(9A):16-20. 